\title{
HARAPAN DIGITAL NATIVE TERHADAP PERPUSTAKAAN MASA DEPAN PADA PERGURUAN TINGGI
}

\author{
Anton Hermawan \\ Dosen Program Studi Perpustakaan \\ Fakultas Teknologi Informasi, Universitas Kristen Satya Wacana \\ Email: anton.hermawan@uksw.edu
}

\begin{abstract}
ABSTRAK
Dalam sepuluh tahun terakhir perkembangan teknologi informasi begitu cepat, hal ini ditandai dengan semakin canggihnya perangkat komunikasi dan meningkatnya penggunaan aplikasi. Generasi yang dilahirkan pada saat dimulainya peralihan teknologi ini tentunya menjadi generasi yang "beruntung" karena kemudahan yang diperoleh dari dampak perkembangan teknologi yang terjadi. Generasi ini dikenal sebagai digital native, dimana mereka cenderung multitasking, berjejaring, menyukai koneksi interaktif, dsb. Saat ini generasi digital nativejuga merupakan bagian dari perpustakaan perguruan tinggi. Dari pengamatan dan data yang diperoleh, digital nativememiliki perilaku belajar yang unik. Beberapa penelitian menyebutkan bahwa generasi digital nativecenderung lebih menyukai mendapatkan informasi dengan cepat dan serba online dengan mengandalkan akses internet. Oleh karena itu, hal ini diduga menjadi penyebab mengapa perpustakaan sudah tidak menarik lagi untuk dikunjungi oleh mahasiswa yang sebagian besar merupakan generasi digital native. Untuk memahami ketertarikan mereka terhadap perpustakaan masa depan penelitian ini berusaha untuk mengetahui harapan digital nativeterhadap perpustakan masa depan dilihat dari sisi gedung dan tata ruang, layanan, dan produk perpustakaan. Penelitian ini menggunakan metode statistik deskriptif, populasinya adalah mahasiswa Fakultas Teknologi Informasi Universitas Kristen Satya Wacana. Sampel yang ditentukan adalah 100 responden. Hasil penelitian ini, diharapkan mampu mengembangkan strategi perpustakaan perguruan tinggi yang berfokus pada digital native.
\end{abstract}

Kata kunci: digital native, harapan digital native, perpustakaan perguruan tinggi, perpustakaan masa depan

\section{ABSTRACT}

In the last ten years the development of information technology is so fast, this is marked by the increasingly sophisticated communication devices and the increasing use of applications. The generation that was born at the start of the transition of technology is certainly a generation that is "lucky" because of the convenience obtained from the impact of technological developments that occur. This generation is known as digital native, where they tend to multitask, network, like interactive connections, etc. At present the native digital generation is also part of the college library. From observations and data obtained, digital nativehas a unique learning behavior. Some studies suggest that native digital generations tend to prefer getting information quickly and completely online by relying on internet access. Therefore, this is thought to be the reason why the library is no longer interesting to be visited by students who are mostly digital nativegeneration. To understand their interest in the library of the future, this research seeks to find out digital nativeexpectations of the future library in terms of building and spatial planning, services, and library products. This study uses descriptive statistical methods, the population is Satya Wacana Christian University's Faculty of Information Technology. The sample determined was 100 respondents. The results of this 
study are expected to be able to develop a university library strategy that focuses on digital native.

Keyword: native digital, the expectation of native digital, university library, the future library

\section{PENDAHULUAN}

Perkembangan teknologi saat ini telah melewati beberapa tahap perkembangan industri. Revolusi 1.0 yang terjadi pada abad 18 merupakan awal revolusi industri yang ditandai dengan beralihnya tenaga manusia ke mesin uap. Revolusi 2.0 yang terjadi pada abad 20, dimana terjadi peralihan dengan digantikannya mesin uap menjadi mesin bertenaga listrik. Pada revolusi 3.0 ditandai oleh otomasi mesin, yang dikendalikan oleh komputer dan robot. Dan pada revolusi 4.0 ditandai dengan ditanamkannya teknologi cerdas yang dapat terhubung dengan berbagai bidang kehidupan manusia, dimana internet of things (IoT) dan kecerdasan buatan (artificial intelligence ) memegang peran yang begitu penting.

Seiring dengan perkembangan revolusi industri 4.0 tentu hal ini memunculkan fenomena yang lain. Fenomena tersebut salah satunya adalah munculnya digital native, digital native merupakan generasi yang lahir pada era digital (Prensky, 2001). Generasi digital native dilahirkan dalam lingkungan digital, dimana mereka mengenal teknologi digital sejak dini. Generasi digital native terbiasa mengisi kehidupannya dengan perangkat teknologi digital (gadget) seperti komputer, action cam, telepon seluler, android, video games, digital music player, notebook, ipad, dsb. Perangkat digital tersebut menjadi kehidupan sehari-hari bagi generasi digital native, sehingga menganggap teknologi digital sebagai bagian yang tidak terpisahkan dari kehidupannya. Oleh karena itu, hal ini tentunya mempengaruhi gaya hidup mereka termasuk cara memperoleh informasi. Perlu disadari bahwa perguruan tinggi pada jaman ini sebagian besar mahasiswanya merupakan generasi digital native. Mereka belajar dimana informasi dapat diperoleh dengan cepat melalui perkembangan teknologi informasi. Hal ini tentunya berdampak terhadap perpustakaan sebagai sumber informasi, agar tidak ditinggalkan oleh pemustakanya. Menyiasati hal tersebut maka perpustakaan perlu untuk mengetahui apa yang diharapan oleh generasi digital native terhadap perpustakaan masa depan. Dalam penelitian ini, harapan digital native dibatasi atas tampilan fisik perpustakaan seperti: bentuk Gedung dan tata ruang, tata ruang,dsbnya, produk perpustakaan dan layanan perpustakaan. Dengan memahami harapan generasi digital native terhadap perpustakaan khususnya perpustakaan perguruan tinggi, tentunya akan lebih memudahkan perpustakaan perguruan tinggi untuk merancang strategi pengembangan perpustakaan dimasa depan. Jika penelitian lain lebih fokus pada bagaimana mempersiapkan dan membangun sebuah perpustakaan digital, penelitian ini lebih fokus pada pemustakaan yang sebagian besar adalah digital native terkait dengan harapannya terhadap perpustakaan masa depan khususnya perpustakaan perguruan tinggi. 


\section{Tinjauan Pustaka \\ Harapan}

Dalam Kamus Besar Bahasa Indonesia (KKBI), harapan adalah keinginan supaya sesuatu terjadi. Harapan yang dimaksud dalam penelitian ini identik dengan hope (harapan). Hope digunakan untuk harapan yang tingkat kemungkinaanya sangat tinggi. Hope bisa digunakan untuk merujuk pada harapan masa lalu, sekarang, ataupun masa depan. Akan tetapi, umumnya digunakan untuk merujuk harapan saat ini atau yang akan terjadi di masa yang akan datang. Hill (dalam Febrianti, 2007:103) menyebutkan bahwa harapan adalah apa yang perlu disediakan oleh penyedia jasa dari apa yang dipikirkan konsumen. Dalam tulisan ini konsumen disini adalah pemustaka. Lebih dalam lagi disebutkan bahwa harapan seorang konsumen adalah apa yang diinginkan terhadap sebuah produk/ jasa guna memenuhi kebutuhannya. Harapan disinyalir dapat berubah-ubah mengikuti perkembangan lingkungan sosial budaya, kemajuan teknologi dan ekonomi. Menurut Anderson dan Chambers (1985), Harapan identik dengan ekspektasi, mengatakan bahwa ekspektasi adalah segala sesuatu yang diyakini konsumen tentang apa yang akan didapatkannya terkait dengan suatu kinerja produk atau pelayanan tertentu. Dari uraian diatas maka harapan dapat disimpulkan sebagai suatu keinginan yang diyakini oleh konsumen (dalam hal ini pemustaka) dapat terwujud.

\section{Digital native}

Istilah digital native pertama kali diperkenalkan oleh seorang konsultan pendidikan bernama Marc Prensky (2001). Digital native diartikan sebagai generasi sejak lahir telah mengenal teknologi. Generasi digital native dilahirkan dilingkungan yang mengkondisikan untuk menggunakan teknologi dalam kehidupan sehari-hari. Generasi digital native dikenal terbiasa mengoperasikan gadget, oleh karena itu generasi digital native juga sering disebut sebagai generasi gadget. Generasi digital native memiliki kecenderungan untuk selalu terhubung dengan jaringan internet setiap hari, menyukai game online, familiar dengan media sosial, senang berbagi di media sosial, Sedangkan menurut Gaith (2010), karakteristik dari generasi digital native adalah menyukai aktifitas online, akses cepat terhadap informasi, berjejaring, multitasking dan keinginan untuk dihargai orang lain.

\section{Gedung dan tata ruang}

Perpustakaan merupakan unit yang sangat penting dan menunjang bagi aktifitas akademik sebuah perguruan tinggi. Melalui perpustakaan begitu banyak ilmu pengetahuan dapat digali untuk menunjang tercapainya visi misi dan perkembangan perguruan tinggi itu sendiri. Oleh karena itu, gedung dan tata ruang perpustakaan biasa menjadi unit yang terpisah dari unit lainnya. Dari survey yang dilakukan Rainathami (2002: 60) menmgenai hubungan antara kondisi fisik gedung dan desain interior ruangan perpustakaan dengan minat menggunakan jasa layanan perpustakaan, diperoleh fakta bahwa kondisi ruangan, warna, cahaya, furniture dan penataan ruang berpengaruh cukup signifikan terhadap minat menggunakan jasa layanan perpustakaan. Sedangkan menurut Sout, menyebutkan bahwa guna menarik masyarakat untuk berkunjung ke perpustakaan diperlukan untuk melakukan desain 
ulang terhadap sebuah perpustakaan. Temuan yang dikemukankan Nuffida (2016), menyebutkan bahwa desain gedung tidak semata-mata produk budaya saja tetapi terkait juga dengan konsumsi visual bagi orang yang melihatnya dan menawarkan pengalaman yang menyenangkan.

\section{Produk}

Dalam dunia pemasaran dikenal dengan istilah bauran pemasaran atau marketing mix. Terdapat empat konsep utama dalam bauran pemasaran, diantaranya adalah produk (product), harga (price), tempat / distribusi (place) dan promosi (promotion). Perpustakaan tidak menjual produk barang walaupun fisik produknya dapat ditemui, tetapi produk jasa, khususnya jasa informasi. Produk dalam ruang lingkup perpustakaan disebut juga dengan istilah koleksi. Menurut Kohar (2003), mendefinisikan koleksi sebagai segala format bahan sesuai dengan perkembangan dan kebutuhan alternatif bagi pengguna perpustakaan terhadap media rekam informasi.

Sedangkan arti koleksi jika mengutip dari ALA Glossary of Library and Information Science (1983) adalah sebagai berikut: "A term which encompasses a number of activities related to the development of the library collection, including the determination and coordination of selection policy, assessment of needs of users and potential users, collection use studies, collection evaluation, identification of collection needs, selection of materials, planning for resource sharing, collection maintenance, and weeding". Diterjemahkan sebagai pengembangan koleksi merupakan sejumlah kegiatan yang berkaitan dengan penentuan dan koordinasi kebijakan seleksi, menilai kebutuhan pemakai, studi pemakaian koleksi, evaluasi koleksi, identifikasi kebutuhan koleksi, seleksi bahan perpustakaan, perencanaan kerjasama sumberdaya koleksi, pemeliharaan koleksi dan penyiangan koleksi perpustakaan. Menurut Billing (1998), koleksi perpustakaan adalah semua bahan perpustakaan yang dikumpulkan, diolah, dan disimpan untuk disajikan kepada masyarakat guna memenuhi kebutuhan pengguna akan informasi. Yulia menyebutkan terdapat dua jenis koleksi/ produk perpustakaan, yaitu 1) tercetak diantaranya: buku, terbitan berseri, peta, gambar, brosur, pamphlet, booklet, dan makalah ; 2) non cetak, seperti: rekaman gambar (film, video, cd, microfilm,dsb) rekaman suara, dan rekaman data magnetik/ digital. Dapat disimpulkan bahwa koleksi/ produk perpustakaan perguruan tinggi adalah segala bahan pustaka yang disediakan dan sesuai dengan kebutuhan sivitas akademika sehingga informasi yang ada didalamnya dapat digunakan oleh para pengguna perpustakaan tersebut. Mardiana menyebutkan bahwa penggunaan teknologi informasi terhadap produk perpustakaan dinegara maju seperti Amerika Serikat telah banyak dilakukan. Hal tersebut antara lain penggunaan e-books dengan aplikasi iBook2, yaitu buku diktat interaktif yang bisa diakses melalui iPad dengan mengkombinasikan animasi 3D dan video; I-tune U, merupakan mata pelajaran online yang dapat diunduh gratis; iBook Author (garageband) bermanfaat untuk menciptakan buku pelajaran sendiri dengan menambahkan fitur interaktif; e-books reader yang tidak hanya dalam bentuk teks 
tetapi kombinasi animasi,video dan suara yang bersifat interaktif.

\section{Layanan}

Menurut Saleh (2014: 4.3), layanan dapat definisikan sebagai aktivitas perpustakaan dalam memberikan jasa layanan kepada pengguna perpustakaan khususnya kepada anggota perpustakaannya. Layanan yang dimaksud adalah sebagai berikut: layanan sirkulasi, layanan referensi, layanan pendidikan pemakai, layanan penelusuran informasi, layanan penyebarluasan informasi terbaru, layanan informasi terseleksi, layanan penerjemah, layanan fotokopi, layanan anak, layana remaja, layanan kelompok pembaca khusus, layanan perpustakaan keliling. Sedangkan Ulumi (2014: 2.11), menyebutkan beberapa layanan perpustakaan adalah layanan sirkulasi, pinjam antar perpustakaan (interlibrary loan), pelatihan untuk pengguna, perpustakaan keliling, fotokopi, ruang baca, study carrel, fasilitas komputer, silang laying, jasa referensi dan informasi, jasa terjemahan, jasa pemencaran informasi terpilih, dan layanan konsultasi.

\section{METODE PENELITIAN}

Pendekatan dalam penelitian ini menggunakan pendekatan deskriptif kualitatif. Non probability sampling menjadi metode pengambilan sampel yang digunakan dalam penelitian. Non probability sampling merupakan teknik pengambilan sampel yang tidak memberikan peluang/ kesempatan sama bagi setiap unsur atau anggota populasi untuk dipilih menjadi sampel (Sugiyono, 2003). Dalam penentuan sampel menggunakan teknik sampling insidental. Menurut Sugiyono (2013: 85) sampling insidental adalah pengambilan sampel berdasarkan kebetulan atau siapa saja yang kebetulan bertemu dengan peneliti dan dirasa cocok, dapat dijadikan sampel. Ukuran penentuan jumlah sampel mengacu pada Roscoe (1975), yang menyarankan bahwa besar jumlah sampel yang dianggap layak adalah 30-500. Atas dasar penentuan jumlah sampel tersebut, maka peneliti menggunakan 100 sampel. Adapun pertimbangan jumlah 100 sampel dipilih karena dinilai cukup ideal dan mampu mewakili populasi dalam penelitian ini,

Penelitian ini mengacu kepada pengukuran sikap, maka skala yang digunakan ialah skala likert. Dengan menggunakan skala likert maka variabelvariabel penelitian akan dijabarkan dalam dimensi-dimensi, kemudian dimensidimensi dijabarkan lagi menjadi indikator-indikator. Setelah membentuk indikatorindikator yang terukur, maka dapat membuat item instrumen yang berupa pertanyaan atau pernyataan untuk dijawab oleh responden.

Skala likert yang digunakan memiliki tingkat pernyataan dari jawaban yang paling positif (paling mendukung) sampai paling negatif (tidak mendukung). Dalam penelitian ini diukur dengan enam point skala derajat kesetujuan, yaitu 1= Sangat Tidak Setuju (STS), 2= Tidak Setuju (TS), 3= Agak Tidak Setuju (ATS), 4= Agak Setuju (AS), 5= Setuju (S), 6= Sangat Setuju (SS). Penggunaan skala likert dengan ukuran interval skala 6 dengan tujuan untuk menghindari kecenderungan responden menjawab ragu-ragu atau netral. 
Uji Validitas dalam penelitian ini dilakukan dengan cara corrected item to total correlation yaitu melakukan korelasi antar skor butir pertanyaan dengan total konstruk atau variabel melalui program SPSS 22.00. Dalam pengujian validitas ini digunakan kriteria dari Anzwar (2005) dimana item valid jika korelasi antara item tersebut dengan skor totalnya $>0,25$. Uji reliabilitas adalah alat untuk mengukur suatu kuesioner yang merupakan indikator dari variabel atau konstruk. Suatu kuesioner dikatakan reliabel atau handal jika jawaban seseorang terhadap pernyataan adalah konsisten atau stabil dari waktu ke waktu. Pengujian reliabel dilakukan melalui program SPSS, jika Cronbach Alpha > 0.6 konstruk atau variabel dikatakan reliabel (Nunnally, 1967). Pada penelitian ini, dilakukan pengujian terhadap validitas dan reliabilitas kuesioner. Setelah data diperoleh maka akan dilakukan pengolahan data dan penyajian data.

\section{HASIL DAN PEMBAHASAN}

Berikut ini dijelaskan lebih rinci analisis dan bahasan dari data yang telah dikumpulkan dan diolah oleh peneliti. Berdasarkan jenis kelamin diperoleh 61 persen responden pria dan sisanya responden wanita. Dalam hal kunjungan sekitar $61 \%$ responden menyatakan kadang, hal ini diduga pengguna berkunjung ke perpustakaan perguruan tinggi jika ada keperluan/ tugas saja. Usia 18-20 menduduki tingkat tertinggi dalam hal kunjungan ke perpustakaan, umur tersebut merupakan usia produktif pendidikan atau usia pelajar yang termasuk dalam kategri digital native, sehingga mereka membutuhkan informasi dan ilmu pengetahuan untuk mendukung pendidikan mereka. Sebagian besar responden dari program studi perpustakaan yaitu sebesar $48 \%$ dan $37 \%$ dari program studi sistema informasi, sisanya program studi lain. Secara lebih rinci data karakteristik responden dapat dilihat pada tabel berikut:

Tabel 1. Karakteristik Responden

\begin{tabular}{lll}
\hline & Jumlah Responden & Persen \\
\hline & Jenis Kelamin & \\
\hline \hline Pria & 61 & $61 \%$ \\
Wanita & 39 & $39 \%$ \\
\hline & Frekuensi & \\
\hline \hline Cukup sering & 25 & $25 \%$ \\
Kadang & 61 & $61 \%$ \\
Sering Sekali & 10 & $10 \%$ \\
Belum & 4 & $4 \%$ \\
\hline & Umur Responden & \\
\hline \hline $18-20$ & 81 & $81 \%$ \\
$21-23$ & 15 & $15 \%$ \\
$24-26$ & 4 & $4 \%$
\end{tabular}




\begin{tabular}{lll}
\hline \multicolumn{3}{c}{ Program Studi } \\
\hline \hline DKV & 5 & $5 \%$ \\
Perpustakaan & 48 & $48 \%$ \\
PR & 1 & $1 \%$ \\
PTIK & 1 & $1 \%$ \\
SI & 37 & $37 \%$ \\
TI & 8 & $8 \%$ \\
\hline
\end{tabular}

Dalam pengujian validitas yang dilakukan terhadap varibel gedung dan tata ruang, ternyata diperoleh bahwa nilai korelasi antar skor butir pertanyaan dengan total konstruk atau variabel memiliki nilai diatas 0,25, sehingga dapat dinyatakan semua item pernyataan (6 item) dinyatakan valid/ akurat. Dalam pengujian validitas yang dilakukan terhadap varibel layanan, ternyata diperoleh bahwa nilai korelasi antar skor butir pertanyaan dengan total konstruk atau variabel juga memiliki nilai diatas 0,25 , sehingga dapat dinyatakan semua item pernyataan (9 item) dinyatakan valid/ akurat. Begitu juga dalam pengujian validitas yang dilakukan terhadap varibel produk, ternyata diperoleh bahwa nilai korelasi antar skor butir pertanyaan dengan total konstruk atau variabel memiliki nilai diatas 0,25 , sehingga dapat dinyatakan semua item pernyataan (8 item) dinyatakan valid/ akurat. Untuk uji reliabilitas yang dilakukan terhadap variabel gedung dan tataruang, layanan dan produk ternyata diperoleh nilai berturutturut sebagai berikut 0,$651 ; 0,580$ dan 0,711. Dari hasil tersebut untuk variabel gedung dan tata ruang dan produk dapat dinyatakan reliabel karena memilikinilailebihdari 0,6. Sedangkan uji reliabel pada variable layanan diperoleh nilai 0,580 dimana lebih kecil dari 0,6. Oleh karena itu perlu dilakukan pengujian dengan menyertakan korelasi antar item. Briggs \& Cheek merekomendasikan nilai korelasi antar item 0,2-0,4 masih dapat digolongkan reliabel. Dari pengujian yang dilakukan dengan menyertakan korelasi antar item diperoleh nilai 0,231, yang artinya variabel layanan dapat dinyatakan reliabel.

Tabel 2. Variabel Gedung dan Tataruang

\begin{tabular}{llllll}
\hline \multicolumn{2}{l}{ Pernyataan } & & & & \\
\hline 1 & 2 & 3 & 4 & 5 & 6 \\
\hline
\end{tabular}

Rata-rata pada jawaban ke Modus Persen

\begin{tabular}{llllll}
4.39 & 4.95 & 4.26 & 5.06 & $\mathbf{5 . 2 3}$ & 5.02 \\
\hline $\mathbf{4}$ & $\mathbf{5}$ & 5 & 5 & 6 & 6 \\
$28 \%$ & $\mathbf{5 6 \%}$ & $38 \%$ & $\mathbf{4 8 \%}$ & $43 \%$ & $40 \%$
\end{tabular}

Pada tabel 2 merupakan hasil rata-rata dan jumlah responden terhadap setiap pernyataan yang diajukan dalam instrumen kepada seratus responden. Dari hasil yang 
diperoleh ternyata mayoritas responden yaitu sebesar $56 \%$ setuju terhadap desain gedung perpustakaan yang unik. Dapat diduga bahwa keunikan sebuah desain gedung perpustakaan dapat menarik pemustaka yang sebagian besar adalah digital native untuk berkunjung dan memanfaatkan bahan bacaan yang tersedia. Lebih spesifik lagi, desain gedung perpustakaan yang futuristik, hal ini ditunjukkan dengan mayoritas responden yang memilih sebesar $48 \%$. Sedangkan terkait tata ruang, ternyata sekitar $43 \%$ responden setuju terhadap desain tata ruang perpustakaan yang modern.

Tabel 3. Variabel Layanan

\begin{tabular}{lllllllll}
\hline Pernyataan & & & & & & & \\
\hline 1 & 2 & 3 & 4 & 5 & 6 & 7 & 8 & 9 \\
\hline
\end{tabular}

Rata-rata pada jawaban ke

Modus

Persen

\begin{tabular}{lllllllll}
5.22 & 4.90 & 5.30 & 4.32 & 5.01 & 4.57 & 4.91 & 5.15 & 5.20 \\
\hline 5 & 5 & 6 & 5 & 5 & 5 & $\mathbf{5}$ & 6 & 5 \\
\hline 45 & & & & & & & 40 &
\end{tabular}

Terkait dengan pelayanan, dari hasil tabel 3 ternyata $48 \%$ responden setuju terhadap penyediaan scanner portable diruang baca dibandingkan penyediaan fotocopy. Hal ini diduga karena sebagian besar pemustaka yang merupakan digital native dimana mereka telah terbiasa dengan teknologi, selain itu multitasking bisa menjadi alasan karena sambil mengerjakan pekerjaan mereka dapat melakukan scaning terhadap data yang dibutuhkan.Temuan lain dari variabel layanan adalah, sebagian besar responden yaitu $46 \%$ menyatakan bahwa membutuhkan akses online terhapad data yang berbentuk audio atau video. Tentunya hal ini sesuai dengan perilaku digital native yang diungkapkan Gaith (2010) dimana cenderung menyukai akses cepat terhadap sebuah informasi.

Tabel 4. Variabel Produk

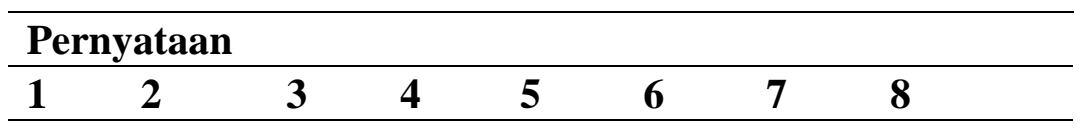

Rata-rata pada jawaban ke

Modus

Persen

\begin{tabular}{llllllll}
4.14 & 4.39 & 4.29 & 4.3 & 4.8 & 4.72 & 5.14 & 5.25 \\
\hline 4 & 4 & 5 & 4 & 5 & 5 & 5 & 6 \\
\hline $34 \%$ & $39 \%$ & $38 \%$ & $35 \%$ & $\mathbf{4 5 \%}$ & $43 \%$ & $\mathbf{4 5 \%}$ & $\mathbf{5 2 \%}$ \\
\hline
\end{tabular}

Untuk variabel produk diperoleh fakta bahwa 52\% responden setuju terhadap akses produk yang dibuka selama 24 jam. Hal yang menarik adalah sebesar $45 \%$ 
responden tertarik diaplikasikannya teknologi virtual reality dan augmented reality dalam sebuah perpustakaan. Hal ini diduga karena pemustaka yang sebagin besar digital native dikenal sudah cukup familiar terhadap teknologi sejak lahir, tetapi teknologi virtual reality dan augmented reality yang terkait dengan dunia perpustakaan masih jarang atau bahkan belum pernah dilihat/ dirasakan.

\section{SIMPULAN}

Dapat disimpulkan bahwa untuk variabel gedung dan tataruang, sebagian besar digital native sebagai pengguna perpustakaan perguruan tinggi berharap memiliki gedung perpustakaan yang unik bergaya futuristik yang didalamnya terdapat ruanganruangan bergaya modern. Sedangkan untuk variabel layanan, diperoleh fakta bahwa sebagian besar digital native sebagai pengguna perpustakaan perguruan tinggi berharap didalam ruang baca dilengkapi dengan scanner potable serta adanya akses online terhadap data audio atau video. Kemudian untuk variabel produk diperoleh fakta bahwa sebagian besar digital native sebagai pengguna perpustakaan perguruan tinggi berharap adanya akses 24 jam terhadap produk perpustakaan serta penggunaan virtual reality dan augmented reality yang dikakitkan dengan produk perpustakaan.

Dari kesimpulan tersebut diatas beberapa rekomendasi implikasi yang dapat ditawarkan adalah sebagai berikut: 1.) melakukan renovasi gedung bergaya futuristik serta ruangan dengan gaya modern untuk memenuhi harapan konsumen yang sebagian besar adalah digital native; 2.)Penyediaan scanner portable di ruangan bagi pengguna perpustakaan, terkait hal ini perlu dipertimbangkan standar operasional prosedur/ SOP untuk keperluan pengawasan dan pengendalian. 3.) Penyedian akses terbatas online terhadap audio atau video melalui jaringan internet.4.) membangun / menciptakan proyek yang mengkaitkan virtual reality dan augmented reality dengan produk perpustakaan, misalnya: pengaplikasian buku sejarah peradaban dengan teknologi virtual reality; penggunaan augmented reality untuk pencarian di rak buku, dsb.

\section{Referensi}

Anzwar, Saifuddin. 2005. Metode Penelitian. Pustaka Pelajar.

Anderson, Paul F. dan Terry M. Chambers. A Reward/ Measurement Model of Organizational Buying Behavior Author(s). Journal of Marketing, Vol. 49, No. 2 (Spring, 1985), p. 7-23. American Marketing Association.

Febrianti, Evi, Iwan Eko Setyawan dan Sienny Thio. 2007. Analisa Harapan dan Persepsi Konsumen terhadap Dimensi Website Hotel Bintang Lima di Surabaya. Jurnal Manajemen, volume 3(September), hal. 102-113.

Josep, S \& Linley, P. 2004. Positive Psychology in Practice, chapter 24. Wiley: United States of America. 
Kohar, Ade. 2003. Teknik Penyusunan Kebijakan Pengembangan Koleksi Perpustakaan: Suatu Implementasi Studi Retrospektif. Media Pratama: Jakarta.

Lopez, Shane J. 2009. The Encyclopedia of Positive Psychology. Volume 1.

Nunnally, J.C. 1967. Psychometric Theory. McGraw-Hill: New York.

Nuffida, Nur Endah, Josep Prijotomo, dan Murni Rachmawati. 2016. Fenomena Entertainment Architecture di Indonesia dan Perkembangan dalam Arsitektur. EMARA Indonesian Journal of Architecture, vol.2 no.2 - Desember 2016.

Prensky, Mark. 2001. Digital native, digital immigrant.On the Horizon. MCB University Press

Rainathami, Herika (2002). Penataan ruang perpustakaan sebagai penunjang perpustakaan perguruan tinggi dalam sekapur sirih pendidikan perpustakaan di Indonesia 1952-2002. Kumpulan artikel alumni dan mahasiswa program studi ilmu perpustakaan program Pascasarjana FIB Universitas Indonesia, Depok.

Roscoe, J.T. 1975. Fundamental Research Statistic for the Behavioral Sciences (2d.ed). Holt, Rinehart and Winston: New York.

Saleh, Abdul Rahman dan Rita Komalasari. 2014. Manajemen Perpustakaan, UT: Jakarta.

Sugiyono. 2003. Statistik untuk Penelitian, cetakan ke-5. Alfabeta: Bandung.

Sugiono. 2013. Metode Penelitian Kuantitatif, Kualitatif dan R\&D. Alfabeta: Bandung.

Siregar, Belling. 1998. Pembinaan Koleksi Perustakaan dan Pengetahuan Literatur. Pembinaan Perpustakaan Sumatera Utara: Medan.

Young, Heartsil. 1983. The ALA Glossary of Library \& Information Science. American Library Association: Chicago.

https://kbbi.web.id/. Kamus Besar Bahasa Indonesia versi online. 